\title{
Electrochemical Corrosion Properties of Ternary Al and Quaternary Zr Added Bell Metal in $0.1 \mathrm{M} \mathrm{NaCl}$ Solution
}

\author{
Sakib Al Razi Khan ${ }^{1}$, Mohammad Ashfaq Hossain ${ }^{1}$, Maglub Al Nur ${ }^{1}$, Mohammad \\ Salim Kaiser ${ }^{2 *}$ \\ ${ }^{1}$ Department of Mechanical Engineering, Bangladesh University of Engineering and Technology, \\ Dhaka, 1000, Bangladesh \\ ${ }^{2}$ Directorate of Advisory, Extension and Research Services, Bangladesh University of Engineering \\ and Technology, Dhaka, 1000, Bangladesh, Tel.: +88-02-9663129; Fax: +88-02-9665622 \\ *Corresponding author: mskaiser@iat.buet.ac.bd
}

\begin{abstract}
The electrochemical corrosion property of ternary $\mathrm{Al}$ and quaternary $\mathrm{Zr}$ added Bell metal in 0.1M Sodium Chloride solution has been experimentally conducted at room temperature. Electrochemical impedance spectroscopy (EIS) method and Potentiodynamic polarization technique are used to carry out the electrochemical investigation. Microhardness test is also conducted for all three alloys and it reveals that $\mathrm{Al}$ addition increases the hardness of bell metal due to the formation of different intermetallic precipitates of $\mathrm{Cu}$ and Al. Optical Micrograph as well as Scanning Electron Micrograph have also been studied to characterize their surface condition. It is found that $\mathrm{Zr}$ addition refines the grain structure of the alloy and results in increase of hardness. The EIS study reveals that the corrosion resistance is seem to be augmented with the addition of ternary $\mathrm{Al}$ and quaternary $\mathrm{Zr}$ to bell metal. The potentiodynamic polarization curves disclose that both ternary $\mathrm{Al}$ added and quaternary $\mathrm{Zr}$ added alloy show better corrosion performance than the base bell metal alloy due to the formation of stable aluminium oxide film. The current density $\left(I_{\text {corr }}\right)$ of base bell metal showed higher value than both ternary Al added and quaternary $\mathrm{Zr}$ added bell metal alloys. The corrosion potential $\left(\mathrm{E}_{\mathrm{corr}}\right)$ and the open circuit potential $(\mathrm{OCP})$ were seen to be moved to the more positive direction for the $\mathrm{Al}$ and $\mathrm{Zr}$ added alloys. Microstructure and SEM study of the alloys after corrosion revealed a formation of an oxide film on the surface of the ternary $\mathrm{Al}$ and quaternary $\mathrm{Zr}$ added alloys, the probable cause of which is the presence of $\mathrm{Al}$ in the respective alloys.
\end{abstract}

Copyright (C) 2021. Journal of Mechanical Engineering Science and Technology.

Keywords: Bell metal, corrosion, EIS, SEM, Tafel

\section{Introduction}

Bell metal is an alloy of copper where the secondary alloying element is tin. Tin has favorable melting point and also has strengthening ability, thereupon when it is added to copper its strength increases as well as it helps to attenuate the rate of corrosion [1]. In bell metal the compositional ratio of copper to tin is approximately $4: 1$ for most of the cases. Bell metal is famous for its unique resonance of sound and therefore most of the musical instruments are made of this promising alloy [2-4]. Other than fabrication of cymbals and percussion instruments, this unique metal is used in war industries as well as making cannons, weapons, forge tools etc. [5]. Due to its attractive color, this alloy material has also a large extent of use in making utensils, pottery, coins, vessels, ornaments, monuments, sculptures, statues etc. [6, 7]. Bell metal alloys are conventionally found in gear, bushing or bearing type applications due to its ability to endure high strengths and heavy loads [8]. This 
alloy has also many industrial applications such as production of pump impellers, bridge plates, piston rings, seal rings, steam fittings and so on [9].

Corrosion is a phenomenon where breakdown of the metal occurs due to electrochemical reactions. It is degradation of materials' properties due to interactions with environments. Metal is converted into another compound such as oxide or salt by that reaction and leads to loss in desirable properties [10-12]. When tin is added to copper it forms oxides very rapidly which can perform as a superficial shear-strength film and has the ability to attenuate corrosion. However, at accelerated condition the thin oxide layer can be penetrated and come off due to the high value of corrosion. For this very reason, the corrosion resistance of bell metal can be further improved by alloying with other elements [8]. Electrochemical Impedance Spectroscopy analysis is a method of measuring the AC impedances with monitoring the current response when a stimulus of AC voltage is applied to an electrochemical cell. Tafel polarization technique gives insight of estimating the corrosion current $\left(\mathrm{I}_{\text {corr }}\right)$, corrosion potential $\left(\mathrm{E}_{\text {corr }}\right)$ and corrosion rate. With the technological advancement of modern era, these two techniques have become widely popular because of their fast analysis and non-destructive nature [13-16].

The application of bell metal has been extended to variety of above-mentioned industrial employments. Particularly in marine based applications such as ship propellers, valve components, heat exchangers used in diesel marine engines, seawater-corrosion holds a significant issue. It is found from different literature that if different ternary or quaternary element is added to copper-based alloys, its property changes significantly. But it is rare to find any literature where the effect of both $\mathrm{Al}$ and $\mathrm{Zr}$ additions has been investigated particularly into bell metal, much less so of their electrochemical corrosion behavior. In this study ternary $\mathrm{Al}$ and quaternary $\mathrm{Zr}$ are added to bell metal to investigate its strength and density property as well as to find out the effect of these additions on electrochemical corrosion behavior in $0.1 \mathrm{M} \mathrm{NaCl}$ solution through EIS and Tafel polarization techniques. Micrographic analysis of the damaged surfaces of the alloys are also investigated after the electrochemical experiment. A conventional microscope and SEM are used to study the effect of corrosion on the evolution of microstructures before and after corrosion in the experimental alloys due to the change in their chemical history.

\section{Material and Methods}

Three samples of bell metal were fabricated individually through continuous casting and melting process where the Alloy 1 corresponds to the base bell metal, Alloy 2 represents the ternary $\mathrm{Al}$ added bell metal and Alloy 3 stands for the ternary $\mathrm{Al}$ and quaternary $\mathrm{Zr}$ added bell metal. In the process of preparation of the bell metal alloys, the commercially pure copper, tin, aluminium and zirconium were selected for casting. Melting was done in a claygraphite crucible in a natural gas fired pit furnace under suitable flux cover. To fabricate the Alloy 1, 2500gm of copper and 700gm of tin were melted in the clay-graphite crucible while for Alloy 2,74gm of aluminium was added by dipping it into another molten metal of $2500 \mathrm{gm}$ copper and $700 \mathrm{gm}$ tin. Consecutively $\mathrm{Al}+10 \mathrm{wt} \% \mathrm{Zr}$ master alloy of $74 \mathrm{gm}$ was added to another molten copper-tin where the individual composition of copper and tin were as same as the Alloy 1 and Alloy 2 for making the Alloy 3. All three alloys were casted individually. The terminating melting temperature was maintained at about $1300 \pm 15^{\circ} \mathrm{C}$ using Infrared Thermometer. Three molds of stainless steel were preheated at $200^{\circ} \mathrm{C}$. The size of the molds was $20 \mathrm{~mm} \times 150 \mathrm{~mm} \times 150 \mathrm{~mm}$. Water with clay mixture was used inside of those molds to prepare a coating layer and then the melts were poured into them. 
Conventional Optical Emission Spectroscopy (OES) method was used to determine the chemical composition of the alloys and the analysis are specified in Table 1.

After that machining was done on the alloys to remove natural oxide film from the exterior. Rectangular samples $(35 \mathrm{~mm} \times 13 \mathrm{~mm} \times 4 \mathrm{~mm})$ of the alloys were fabricated from the cast products. To prepare a smooth and refined surface the samples were polished with emery papers of 300, 600, 800 and 1200 grits. Micro Vickers Hardness Tester was used to determine the hardness of experimental alloys. Several indentations were taken applied with 1 Kilogram load for the time duration of 10 seconds through a knoop indenter for each sample at different surface locations. A conventional optical microscope OPTIKA was used to characterize the microstructures of the alloys. A wet polishing machine with velvet clothed wheel with the addition of alumina powder was used to make scratch free polished surface. Acetone was applied to clean the surface. Ammonium Hydroxide and 3\% Hydrogen peroxides were used as etchant which were taken in a ratio of 1:1. The whole experiment had been conducted at room temperature.

Electrochemical Impedance Spectroscopy of the experimental alloys was studied through a computerized Gamry Framework TM Series G 300 ${ }^{\mathrm{TM}}$ and Series G $750^{\mathrm{TM}}$ Potentiostat/ Galvanostat/ZRA. To prepare 0.1 Molar concentrated solution of Sodium Chloride, demineralized water, and analytical reagent grade $\mathrm{NaCl}$ were taken where the $\mathrm{pH}$ of the solution was kept neutral. To conduct electrochemical experiment three electrode cell arrangements had been used. A mercury coated with $\mathrm{Hg}_{2} \mathrm{Cl}_{2}$ and $\mathrm{KCl}$ as electrolyte type conventional calomel electrode is prepared as reference electrode. The other two electrodes used were platinum electrode as a counter electrode and experimental alloy sample as working electrode. In case of working electrode, a wire was connected to the experimental sample and only $6.5 \mathrm{~mm} \times 4 \mathrm{~mm}$ surface was kept open to the $\mathrm{NaCl}$ solution while the rest of the surfaces were kept protected by Teflon tape. Before creating Open Circuit Potential, the sinusoidal voltage amplitude was set for $5 \mathrm{mV}$. The frequency range of the experiment was set up for $100 \mathrm{kHz}$ to $0.2 \mathrm{~Hz}$. For ensuring better accuracy in result, the Sodium Chloride solution was refreshed time to time throughout the whole experiment period. The experiment was allowed to terminate from Open Circuit Potential and thereupon a data analysis software Echem Analyst was used to design equivalent circuits whichever fit the best for them. After matching properly with the equivalent circuit from the response data, the value of corresponding circuit components: solution resistance $\left(\mathrm{R}_{\mathrm{s}}\right)$, corrosion resistance $\left(\mathrm{R}_{\mathrm{p}}\right)$ and effective double layer capacitance $\left(\mathrm{C}_{\mathrm{p} \text {-eff }}\right)$ had been calculated.

The Potentiodynamic polarization experiment was also conducted using identical experimental setup used for the EIS study. The range of potential was set from -1 to $+1 \mathrm{~V}$ vs reference electrode. The selected scan rate was $0.50 \mathrm{mV} / \mathrm{s}$. Hence the setup was allowed to generate a steady state Open Circuit Potential. As soon as the experiment was over, the corresponding Tafel plot was generated. The corrosion potential $\left(\mathrm{E}_{\mathrm{corr}}\right)$ in millivolt, corrosion current $\left(\mathrm{I}_{\text {corr }}\right)$ in micro ampere and corrosion rate in mils penetration per year (mpy) were measured from the Tafel polarization plot for all of the experimental alloys. The sample surfaces were seen to be damaged after the experiment and so they were characterized under both conventional optical microscope and Scanning Electron Microscope. The equation used to determine the rate of corrosion rate following ASTM Standard G 102 (equation 1):

Corrosion rate $=\frac{\mathrm{Icorr} \times \mathrm{K} \times \mathrm{E} . \mathrm{W} .}{\mathrm{d} \times \mathrm{A}}$......

where,

$\mathrm{I}_{\text {corr }}=$ corrosion current in amperes 
$\mathrm{K}=$ constant which designates the units of the rate of corrosion (here, $\mathrm{K}=128800 \mathrm{mpy}$ from ASTM Standard G 102)

E. W. = equivalent weight in grams per equivalent $\mathrm{d}=$ density of the sample in grams per cubic centimeters

$\mathrm{A}=$ exposed surface area in square centimeters

Table 1. Chemical composition of the experimental alloys (wt $\%$ ).

\begin{tabular}{lllllllllll}
\hline & $\mathrm{Sn}$ & $\mathrm{Pb}$ & $\mathrm{Fe}$ & $\mathrm{Ni}$ & $\mathrm{Al}$ & $\mathrm{Si}$ & $\mathrm{Cr}$ & $\mathrm{Zr}$ & $\mathrm{Mn}$ & $\mathrm{Cu}$ \\
\hline Alloy 1 & 24.935 & 0.000 & 0.000 & 0.019 & 0.005 & 0.001 & 0.004 & 0.000 & 0.001 & $\mathrm{Bal}$ \\
Alloy 2 & 25.444 & 0.000 & 0.012 & 0.018 & 1.165 & 0.007 & 0.003 & 0.000 & 0.001 & $\mathrm{Bal}$ \\
Alloy 3 & 25.008 & 0.010 & 0.020 & 0.018 & 1.170 & 0.002 & 0.004 & 0.240 & 0.002 & $\mathrm{Bal}$ \\
\hline
\end{tabular}

\section{Results and Discussions}

\section{A. Microhardness Test}

The microhardness test results of the experimental alloys are shown in Figure 1. The graph depicts that pure bell metal (Alloy 1) shows the least hardness. The ternary Al added bell metal (Alloy 2) shows a bit higher hardness while the ternary $\mathrm{Al}$ and quaternary $\mathrm{Zr}$ added bell metal (Alloy 3) shows the highest value of microhardness. Bell metal shows considerable hardness value due to the presence of high tin content [17]. But it is evident that the microhardness of the bell metal increases with the ternary addition of aluminium and it further increases due to quaternary addition of zirconium. Al is known to cause significant hardening when added to $\mathrm{Cu}-\mathrm{Sn}$ alloys [18]. This hardening is caused by the formation of intermetallic precipitates formed by the reaction between $\mathrm{Al}$ and $\mathrm{Cu}$ during solidification of the alloy. $\mathrm{Al}_{2} \mathrm{Cu}, \mathrm{Al}_{4} \mathrm{Cu}_{9}$ and $\mathrm{Cu}_{3} \mathrm{Al}_{2}$ are among the intermetallic compounds responsible for the increase in hardness of the alloy [19]. Addition of $\mathrm{Zr}$ is also known to increase the hardness and strength of copper alloys [20]. Through grain refinement the formation of intermetallic compounds such as $\mathrm{Al}_{3} \mathrm{Zr}$ attributes to the increase in hardness of the alloy [21].

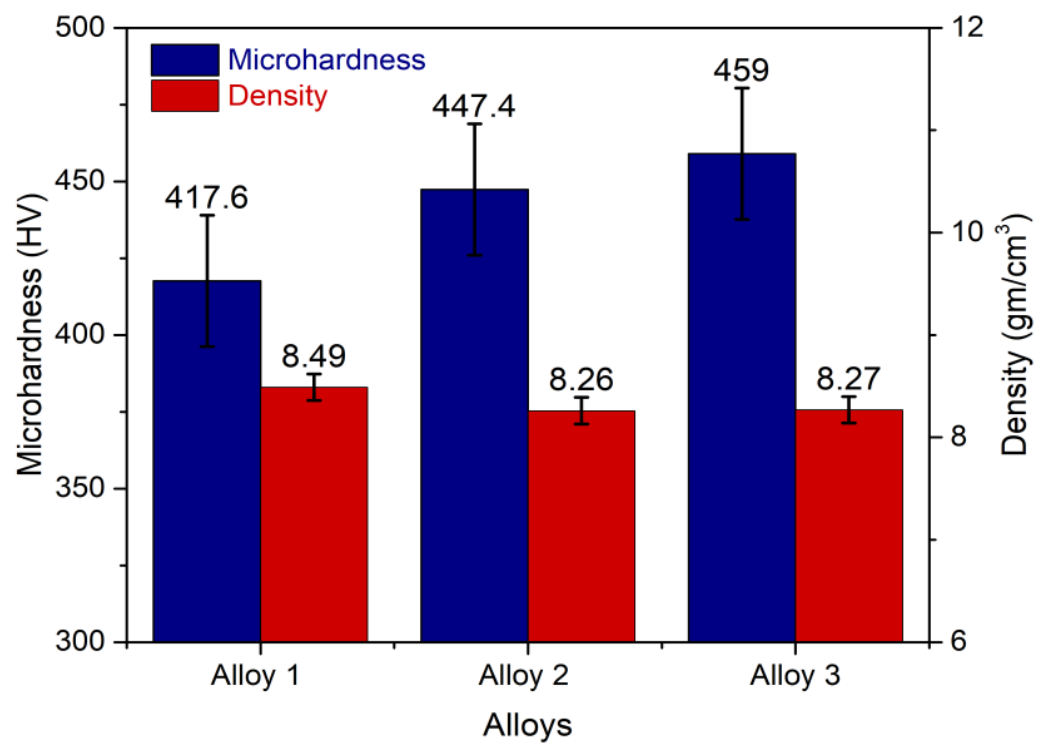

Fig. 1. Variation of hardness and density of the alloys at room temperature 
Figure 1 also shows the density of all three alloys, representing the variation of density with the alloying addition of $\mathrm{Al}$ and $\mathrm{Zr}$. As the density of $\mathrm{Al}$ is less than that of $\mathrm{Cu}$, the density of the bell metal decreases due to the ternary addition of Al. The density increases slightly with quaternary addition of $\mathrm{Zr}$ in Alloy 3, as the density of $\mathrm{Zr}$ is a bit higher than that of Al.

\section{B. Impedance Measurement}

Table 2 shows the experimental results from Electrochemical Impedance Spectroscopy (EIS) test.

Table 2. Electrochemical Impedance Spectroscopy (EIS) test results

\begin{tabular}{cccccc}
\hline $\begin{array}{c}\text { Alloy } \\
\text { Composition }\end{array}$ & $\begin{array}{c}\text { Solution } \\
\text { Resistance } \\
{\left[\mathrm{R}_{\mathrm{s}} \text { in } \Omega\right]}\end{array}$ & $\begin{array}{c}\text { Polarization } \\
\text { Resistance } \\
{\left[\mathrm{R}_{\mathrm{p}} \text { in } \Omega\right]}\end{array}$ & $\begin{array}{c}\text { Effective } \\
\text { Double Layer } \\
\text { Capacitance } \\
{\left[\mathrm{C}_{\mathrm{p} \text { (eff) }} \text { in } \mu \mathrm{F}\right]}\end{array}$ & $\begin{array}{c}\text { Open Circuit } \\
\text { Potential } \\
{[\text { OCP in }} \\
\text { V/SCE] }\end{array}$ & $\begin{array}{c}\text { Goodness } \\
\text { of Fit }\end{array}$ \\
\hline Alloy 1 & 46.93 & 551.2 & 12.15 & -0.0698 & 0.0039 \\
Alloy 2 & 39.76 & 714.1 & 9.33 & -0.0457 & 0.0174 \\
Alloy 3 & 40.81 & 789.7 & 8.47 & -0.0431 & 0.0209 \\
\hline
\end{tabular}

The experimental data obtained from the Potentiostatic EIS test were simulated through Echem Analyst data analysis software thereupon several equivalent circuits were modeled from which the best fitted one is presented in Figure 2. $R_{S}$ denotes the ohmic solution resistance of the electrolyte where $\mathrm{R}_{\mathrm{ct}}$ represents the charge transfer resistance which is also equivalent to the polarization or corrosion resistance [22]. CPE represents the Constant Phase Element from which effective electrical double layer capacitance value has been obtained [23].

The Nyquist plots of the corresponding equivalent circuit model are represented in Figure 3 for all three experimental bell metal alloys. In Figure 3 the imaginary part of the impedance component ( $\left.Z^{\prime \prime}\right)$ corresponds to the y-axis where the real part of the impedance $\left(Z^{\prime}\right)$ corresponds to the $\mathrm{x}$-axis. The responses are obtained in the model of capacitiveresistive semicircle for the experimental alloys.

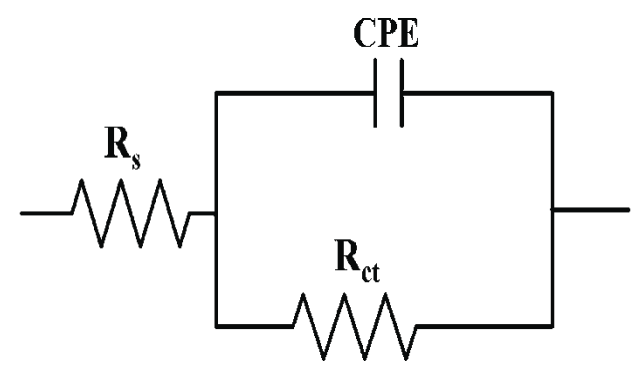

Fig. 2. Electrical equivalent circuit diagram of the impedance data for experimental alloys 


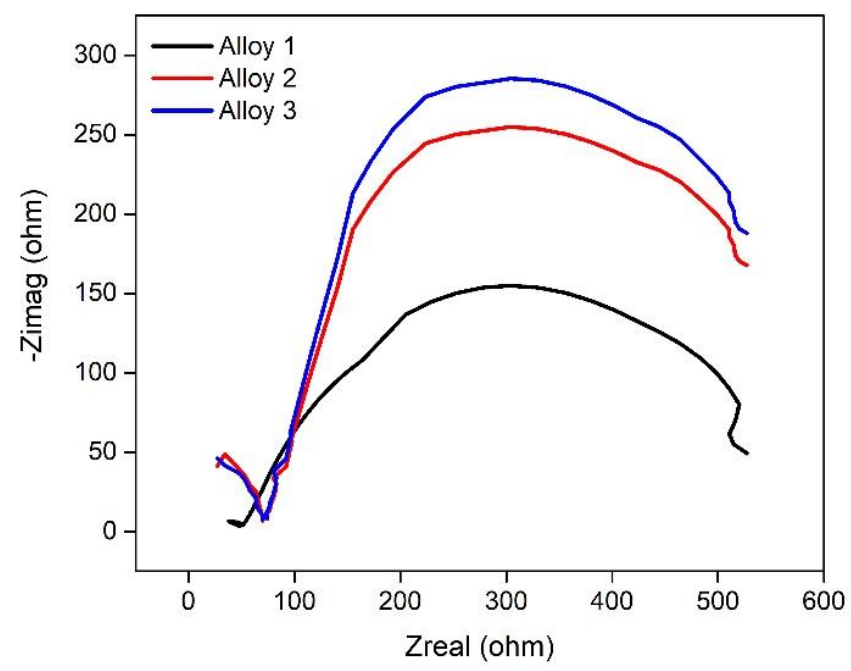

Fig. 3. Nyquist plots for experimental bell metal alloys in $0.1 \mathrm{M} \mathrm{NaCl}$ solution at room temperature

Bode plots for all three bell metal alloys are shown in Figure 4 where the curves are drawn $Z_{\text {mod }}$ against applied frequency. $Z_{\text {mod }}$ represents the total impedance behavior. From Table 2 it is found that the range of $R_{S}$ varies between 39-47 $\Omega$. Therefore, it can be said that there is no significant change observed for $R_{\mathrm{S}}$ values while EIS testing. In fact, the solution resistance values are seemed quite minor compared to that of polarization resistance. Polarization resistance depends on the working electrode while the solution resistance depends on the solution used for the electrochemical experiment. Table 2 reveals that in 0.1 $\mathrm{M} \mathrm{NaCl}$ solution, addition of ternary $\mathrm{Al}$ and quaternary $\mathrm{Zr}$ in the bell metal alloy enhanced the polarization resistance $\left(R_{p}\right)$. For Alloy 1 , the polarization resistance $\left(R_{p}\right)$ value is $551.2 \Omega$ and increased to the value of $714.1 \Omega$ through the addition of ternary Al to the bell metal (Alloy 2). Alloy 3 showed slightly increased value of polarization resistance $\left(\mathrm{R}_{\mathrm{p}}\right)$ compared to Alloy 2 which is almost $789.7 \Omega$. It is reasonable to assume that the enhanced polarization resistance depicts an increment in the corrosion resistance of bell metal through the ternary and quaternary additions $[24,25]$.

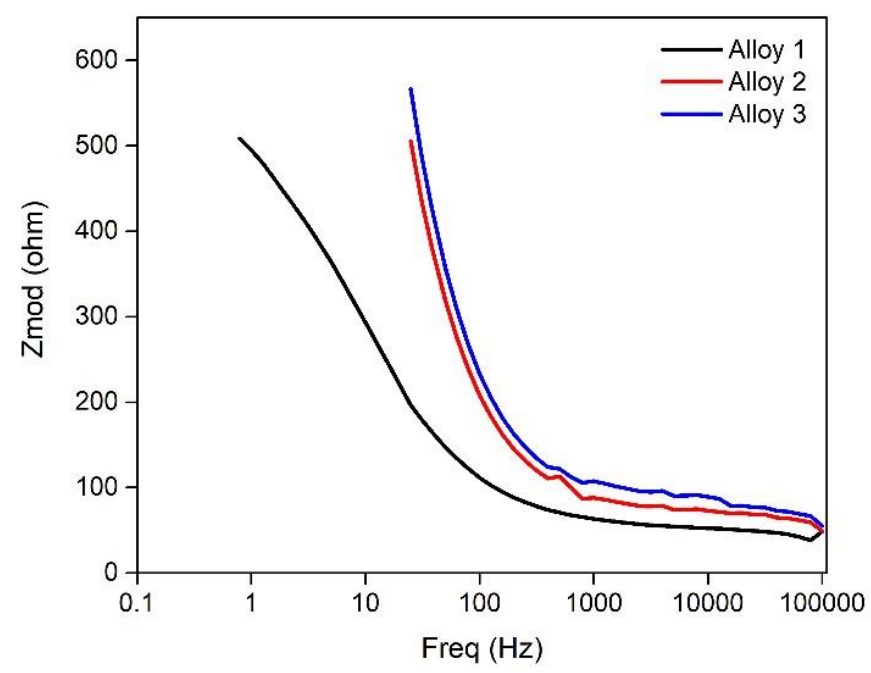

Fig. 4. Bode plots for the experimental alloys in $0.1 \mathrm{M} \mathrm{NaCl}$ solution at room temperature 
The effective double layer capacitance $\left(\mathrm{C}_{\mathrm{p} \text {-eff }}\right)$ of Alloy 1 is $12.15 \mu \mathrm{F}$. With ternary addition of $\mathrm{Al}$ and quaternary addition of $\mathrm{Zr}$, the value of effective double layer capacitance was decreased for both cases. The steady state open circuit potential of base bell metal is $-0.0698 \mathrm{~V}$ which is the most negative among all three of them. The OCP value of Alloy 2 is $-0.0475 \mathrm{~V}$ while Alloy 3 shows slightly more positive value of $-0.0431 \mathrm{~V}$. It is reasonable to assume that the variation of the open circuit voltage is caused by both of the ternary $\mathrm{Al}$ and quaternary $\mathrm{Zr}$ additions.

\section{Potentiodynamic Polarization Analysis}

The results of potentiodynamic polarization analysis conducted from the electrochemical tests is shown in Table 3.

Table 3. Potentiodynamic polarization analysis results

\begin{tabular}{cllc}
\hline $\begin{array}{c}\text { Alloy } \\
\text { Composition }\end{array}$ & $\begin{array}{l}\mathrm{I}_{\text {corr }} \\
{[\mu A]}\end{array}$ & $\begin{array}{l}\mathrm{E}_{\text {corr }} \\
{[\mathrm{mV}]}\end{array}$ & $\begin{array}{c}\text { Corrosion Rate } \\
{[\mathrm{mpy}]}\end{array}$ \\
\hline Alloy 1 & 16.9 & -213 & 27.92 \\
Alloy 2 & 3.4 & -171 & 5.72 \\
Alloy 3 & 3.02 & -72.3 & 4.99 \\
\hline
\end{tabular}

Figure 5 represents the potentiodynamic polarization curves of bell metal alloys in $0.1 \mathrm{M}$ $\mathrm{NaCl}$ solution. With the addition of both ternary $\mathrm{Al}$ and quaternary $\mathrm{Zr}$, anodic current density of bell metal alloys were seen to be attenuated due to the deceleration of the anodic reaction. This ternary and quaternary additions caused the formation of micro-galvanic cells in alpha matrix. The intermetallic precipitates of $\mathrm{Al}_{2} \mathrm{Cu}, \mathrm{Cu}_{3} \mathrm{Al}_{2}$ and $\mathrm{Al}_{4} \mathrm{Cu}_{9}$ are most likely to be formed in ternary $\mathrm{Al}$ added alloys [26]. In case of quaternary $\mathrm{Zr}$ addition, $\mathrm{Cu}_{9} \mathrm{Zr}_{2}$ and $\mathrm{Al}_{3} \mathrm{Zr}$ intermetallics are formed [27, 28]. Corrosion potential difference between alpha matrix and secondary constituents can create due to the formation of those intermetallics which leads to the generation of different micro-galvanic cells [29]. For the base bell metal Alloy 1 corrosion potential $\left(\mathrm{E}_{\mathrm{corr}}\right)$ is $-213 \mathrm{mV}$, which is the most negative potential among the alloys investigated. In case of Alloy 2, ternary $\mathrm{Al}$ addition made the corrosion potential ( $\left.\mathrm{E}_{\text {corr }}\right)$ shifted towards positive value, following that with the addition of quaternary $\mathrm{Zr}$ for Alloy 3 , corrosion potential $\left(\mathrm{E}_{\mathrm{corr}}\right)$ is seemed to be gone to more noble direction. It is also found from the potentiodynamic analysis that the addition of $\mathrm{Al}$ and $\mathrm{Zr}$ in bell metal reduced the corrosion current $\left(\mathrm{I}_{\text {corr }}\right)$. The corrosion current $\left(\mathrm{I}_{\text {corr }}\right)$ value of bell metal Alloy 1 in 0.1 Molar sodium chloride solution was $16.9 \mu \mathrm{A}$, and in case of Alloy 2 this value decreased to $3.4 \mu \mathrm{A}$ with the addition of ternary Al. Alloy 3 showed the lowest corrosion current $\left(\mathrm{I}_{\text {corr }}\right)$ value of $3.02 \mu \mathrm{A}$ among all three alloys. Potentiodynamic polarization test also offers the corresponding corrosion rate in mpy for all three alloys, and it is seen that the corrosion performance of both ternary $\mathrm{Al}$ and quaternary $\mathrm{Zr}$ added alloys were found to be higher than that of base bell metal. It is seen that the Alloy 1 showed corrosion rate of $27.92 \mathrm{mpy}$ where it is decreased to 5.72mpy for Alloy 2. In case of base bell metal Alloy 1 a thin film of Copper Oxide forms while on the other hand for Alloy 2, along with Copper Oxide film, a film of Aluminium Oxide also forms because of additional ternary Al component [30]. Aluminium Oxide is more stable and works as a protective layer where copper shows weaker interaction with oxygen [31]. Moreover, the enthalpy of formation of Aluminium Oxide is less than that of Copper Oxide. The lower the enthalpy of formation of a substance, the lower the energy level of the substance and the lower the energy level of the substance, the more 
stable the substance is. That is why Aluminium Oxide can be said to be more stable than Copper Oxide. Vargel [32] has reported that aluminium as a naturally passive metal, forms two superimposed colorless oxide layers: the first one is internal-compact-amorphous barrier layer which forms within a few milliseconds and the other one is external layer, generally called protective layer which grows on top of the first one. All these result in increased strength of the protective film layer for Alloy 2 where the ternary $\mathrm{Al}$ addition plays the key role. This is the reason behind the better corrosion performance of Alloy 2. In case of Alloy 3 the corrosion rate is found to be $4.99 \mathrm{mpy}$. The quaternary addition of $\mathrm{Zr}$ accelerated the alloy to more positive corrosion performance than Alloy 2. It is because the corroded elements which tend to present in grain boundaries are refined due to the grain refining ability of $\mathrm{Zr}$ and the grains became well distributed [33]. So ternary Al added Alloy 2 and quaternary $\mathrm{Zr}$ added Alloy 3 both seemed to be less prone to corrosion than that of base bell metal Alloy 1 .

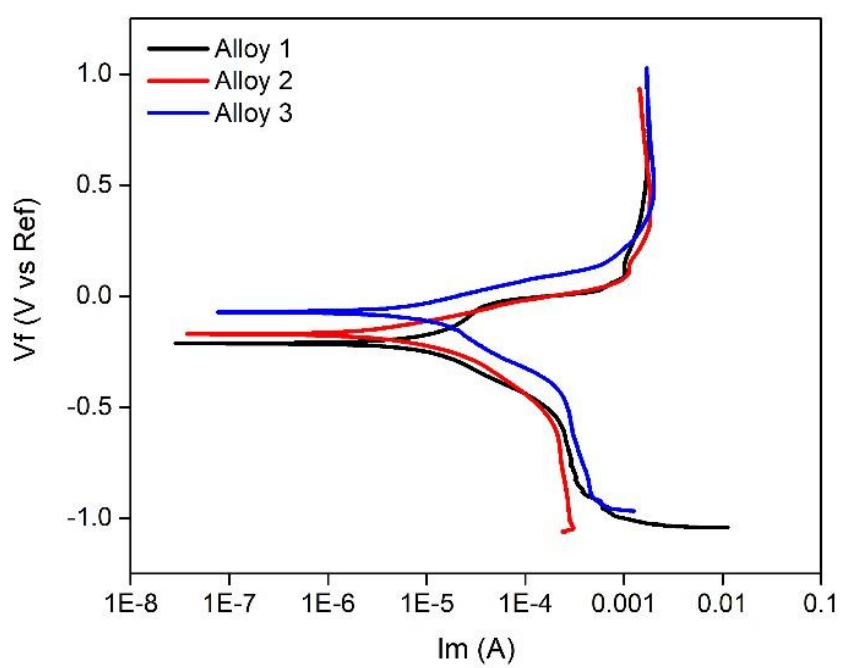

Fig. 5. Tafel polarization curves of the experimental alloys in $0.1 \mathrm{M} \mathrm{NaCl}$ Solution

\section{Optical Micrographic Investigation}

Figure $6 \mathrm{a}, 6 \mathrm{~b}$ and $6 \mathrm{c}$ show the optical micrographs of the polished and etched surface of the experimental alloys. From the micrograph it is seen that the microstructure of Alloy 1 consists of island-like grains of alpha $(\alpha)$ phase particles with Beta $(\beta)$ phase along the grain boundaries (Figure 6a). This is the typical microstructure of a bell metal alloy. The tin content in the bell metal is not high enough to form a complete Beta $(\beta)$ phase [34]. Figure $6 \mathrm{~b}$ shows the optical micrograph of the polished and etched ternary Al added Alloy 2. The addition of $\mathrm{Al}$ changes the island-like grain structure of bell metal. Instead, long dendritic arm structure is seen in the alloy. The presence of aluminium causes the formation of this long dendritic arm microstructure in Alloy $2[35,36]$. Addition of $\mathrm{Zr}$ also influences the microstructure of the alloy, as we see visible changes in the micrograph of Alloy 3. Figure $6 \mathrm{c}$ shows the optical micrograph of polished and etched quaternary $\mathrm{Zr}$ added Alloy 3 . In the micrograph it is seen that the dendritic arm structure appears to be more refined, due to the presence of Zr. Zirconium is a grain refiner [37]. It is commonly known to cause grain refinement of copper alloys when added in small amount [38]. The zirconium present in Alloy 3 reacted with the $\mathrm{Cu}$ and $\mathrm{Al}$ to form $\mathrm{Cu}_{9} \mathrm{Zr}_{2}$ and $\mathrm{Al}_{3} \mathrm{Zr}$ intermetallic compounds respectively $[25,26]$. Grain growth of the alloy is restricted due to the formation of these 
intermetallic precipitates [39]. This causes the grain structure to be refined and more evenly distributed.
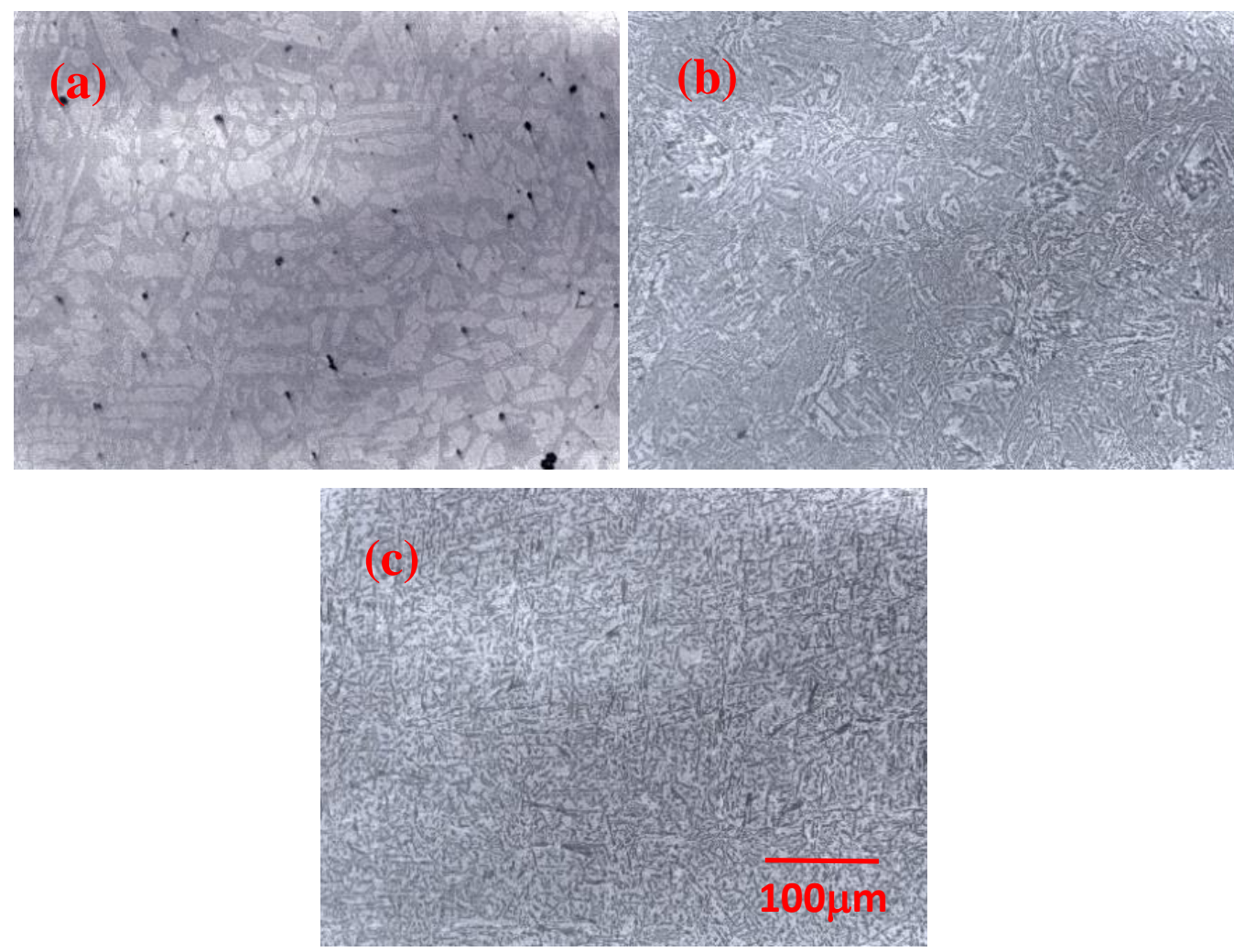

Fig. 6. Optical micrograph of the experimental polished cast alloys a) Alloy 1, b) Alloy and c) Alloy 3

The optical micrographs in Figure $7 \mathrm{a}, 7 \mathrm{~b}$ and $7 \mathrm{c}$ show the scratched surface of the experimental alloys before immersion into the corrosion medium. Figure $7 \mathrm{a}$ and $7 \mathrm{~b}$ show the micrographs of the scratched surface of Alloy 1 and Alloy 2 respectively. The addition of $\mathrm{Al}$ changes the island-like grain structure of Alloy 1 and transforms it to a long dendritic arm structure. This change in microstructure can be characterized by the increased dark tone in the micrograph of Alloy 2. Figure 7c shows the optical micrograph of the scratched surface of Alloy 3. In this micrograph the refined grain structure of the alloy can be characterized through the even distribution of the dark tones or patches on the scratched surface of Alloy 3.

Figure $8 \mathrm{a}, 8 \mathrm{~b}$ and $8 \mathrm{c}$ show the optical micrograph of the alloy surfaces after corrosion. Significant corrosion was observed after the electrochemical corrosion study. In Figure 8a the micrograph of Alloy 1 after corrosion shows the evidence of concentrated attack at different locations of the surface caused by dissolution of the corrosion products into the surrounding environment. In comparison Figure $8 \mathrm{~b}$ and $8 \mathrm{c}$ show that the corrosion taking place on the surface of Alloy 2 and Alloy 3 respectively were much more uniform with less localized pit formation. Further investigation of the micrographs of Alloy 2 and 3 show a complete disappearance of the polished marks which suggests a formation of oxide film layer on their surfaces. It is evident that the corrosion product remains on the surface of the alloy because of the lack of dissolution into the surrounding environment. It can be seen from the micrograph of Alloy 3 that the corrosion products are much evenly distributed. The probable cause behind this is the refined grain structure of the quaternary $\mathrm{Zr}$ added Alloy 3. 

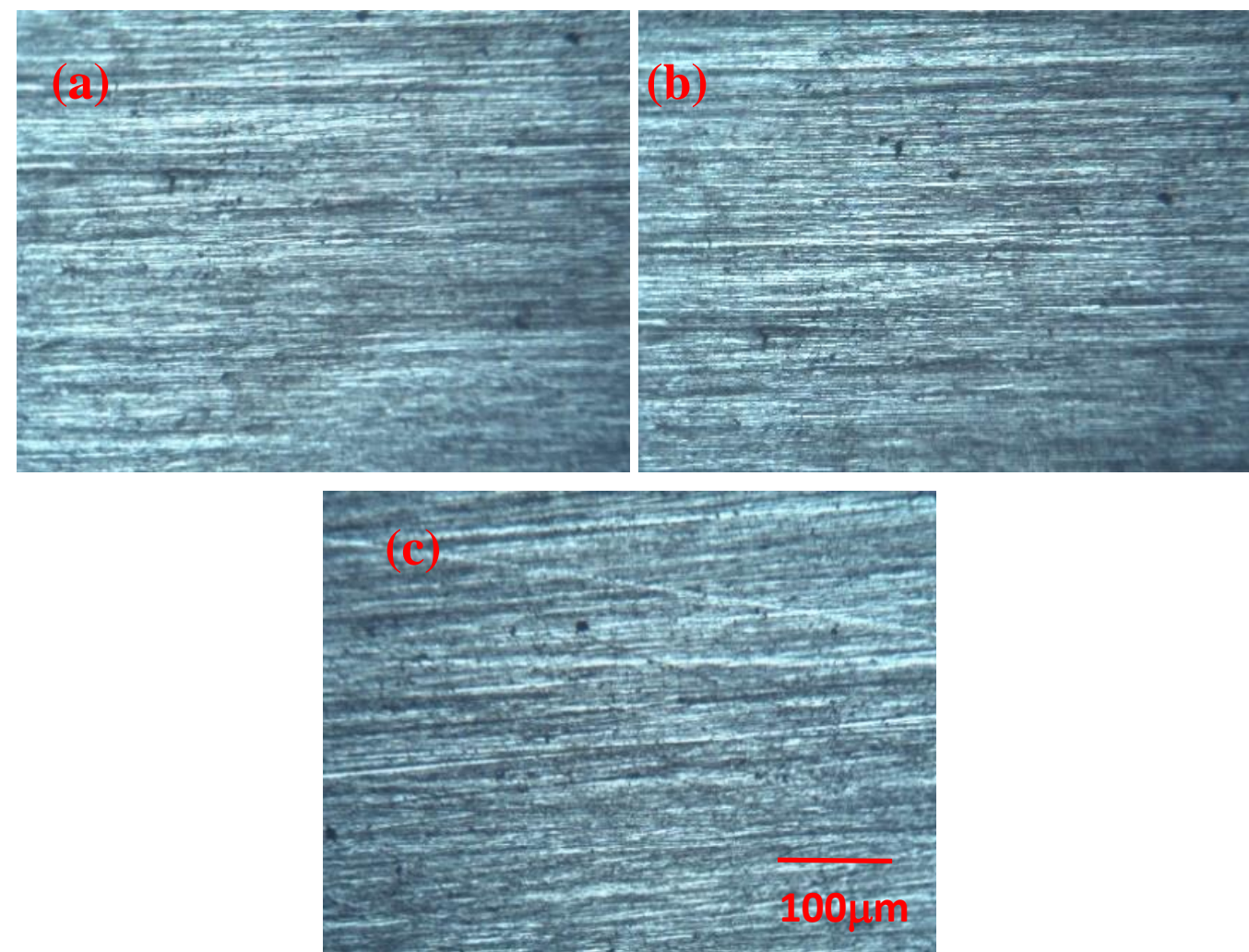

Fig. 7. Microstructure of experimental alloys a) Alloy 1, b) Alloy 2 and c) Alloy 3 before corrosion
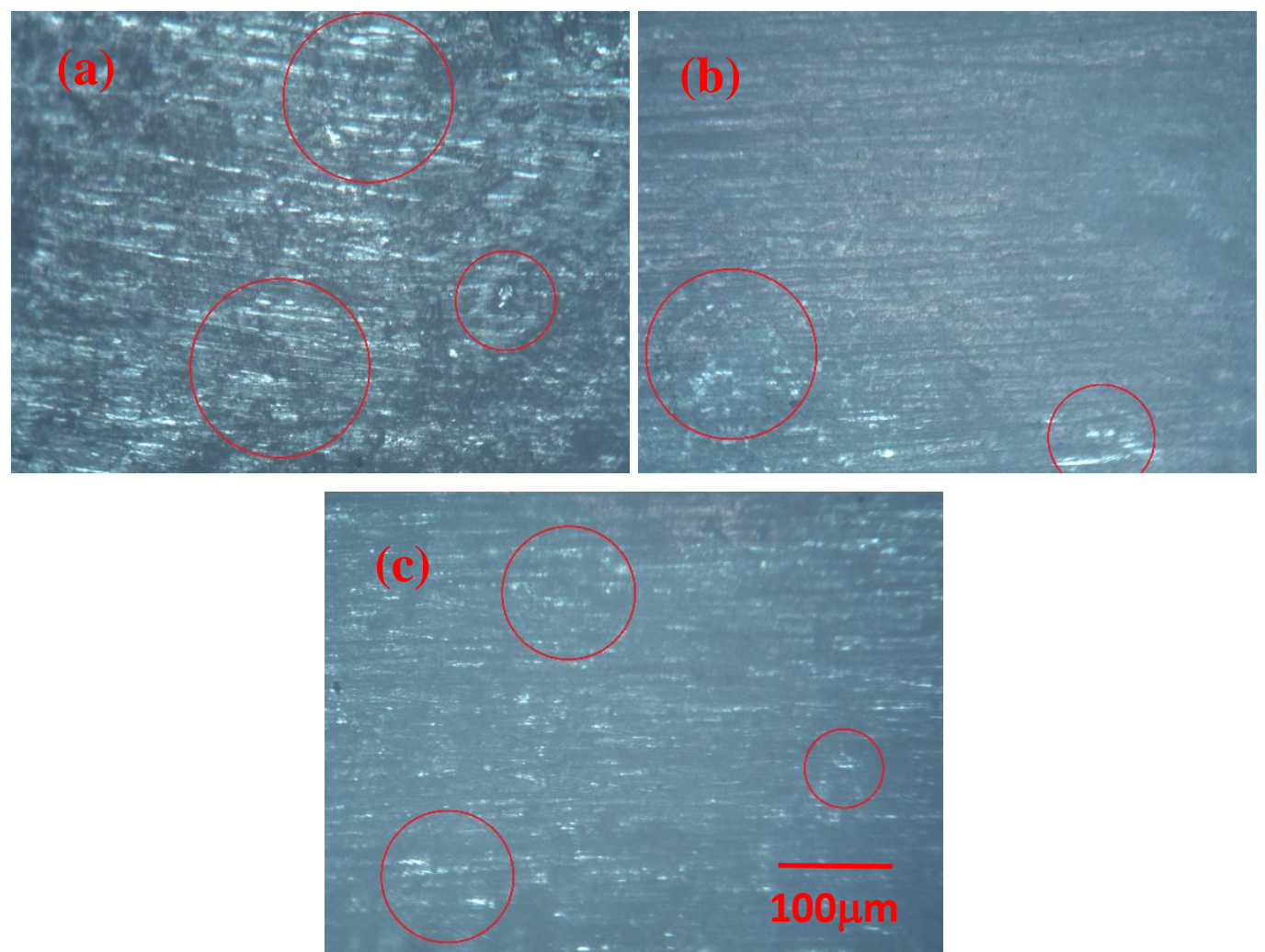

Fig. 8. Microstructure of experimental alloys a) Alloy 1, b) Alloy 2 and c) Alloy 3 after corrosion [The circled zones indicate the formation of localized pits on the alloy surfaces after corrosion. As it can be seen Alloy 2 and 3 show less localized pit formation.] 
The micrographs suggest that Alloy 2 and 3 show better resistances to corrosion and one possible cause of this could be the formation of aluminium oxide at the corroding interface [40]. As it is seen from literature, due to aluminum addition, the formation of dense aluminium oxide layer at the corroding surface can effectively enhance the corrosion resistance of the alloy [41]. In addition, the corrosion resistance of Alloy 3 can be attributed to the microstructural variations caused by the presence of $\mathrm{Zr}$ in the alloy $[42,43]$.

\section{E. SEM Observation}

The SEM images showing the damage surface morphology of the experimental alloys. Alloy 1, 2 and 3 are presented in Figure 9a, 9b and 9c respectively. From the SEM images it is seen that there are evidence of corrosion of intermetallic compounds on the surface of all examined samples. The SEM image of the bell metal Alloy 1 shows the evidence of localized corrosion and discrete pits can be seen on the sample surface. It is also observed that the rough polish marks before immersion into the corrosion medium are visible in the SEM images of Alloy 1. It is probable that the pit formation occurred due to the intermetallic compounds dissolving out of the alloy surface into the surrounding environment. This is the same reason behind the visibility of the rough polish marks on the surface of the alloy. It can also be concluded that the pit formation was caused by selective dissipation of the second phase particles of the alloy.
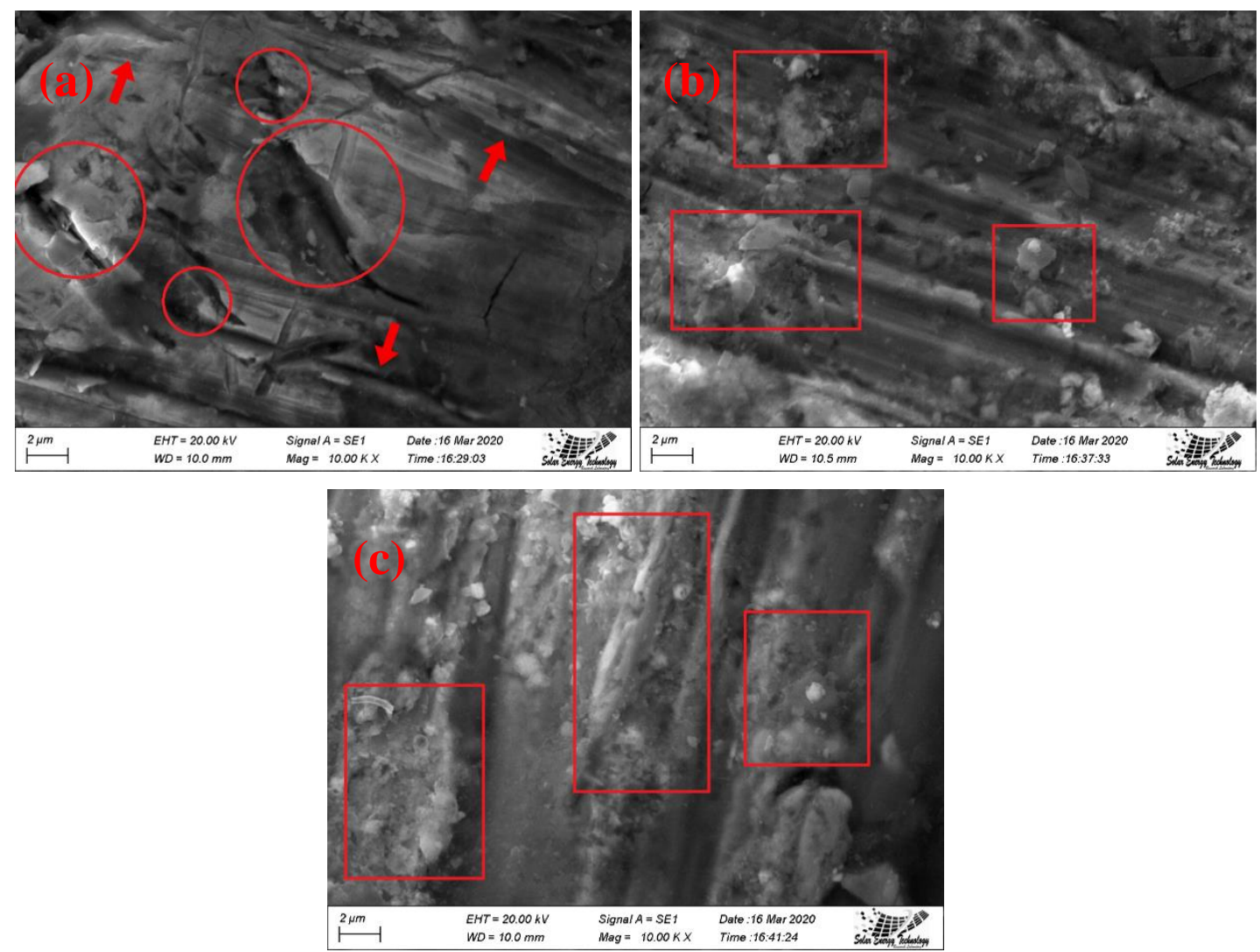

Fig. 9. SEM images show the damage surface morphology of as-corroded (a) Alloy 1, (b) Alloy 2 and c) Alloy 3 [The red circles in (a) indicate the pit formation in Alloy 1 after corrosion. The red arrows in (a) indicate the rough polish mark on the surface of Alloy 1 . The red rectangular zones in ' $b$ ' and ' $c$ ' indicate the corrosion products and oxide films remaining on the surface of Alloy 2 and Alloy 3 respectively. As it is seen the oxide film in Alloy 3 is much denser and more uniformly distributed.] 
One of the main corrosion product of Alloy 1 is copper oxide [44]. It is reasonable to assume that the copper oxide formed during corrosion did not work as a protective layer for the alloy and was dissolved into the solution. SEM images of ternary Al added Alloy 2 and quaternary $\mathrm{Zr}$ added Alloy 3 shows a more uniform form of corrosion. In Figure $9 \mathrm{~b}$ the SEM image of Alloy 2 shows that the polish marks are less visible on the surface of the alloy. It is also seen from the SEM image that most of the corrosion products remain on the sample surface and there were no dissolution of corrosion products into the surrounding matrix. It is reasonable to opine on the basis of literature and previous works that due to small amount of ternary $\mathrm{Al}$ addition, aluminium oxide was formed on the surface of the alloy [45]. This aluminium oxide acted as a protective layer on the corroding interface, causing the corrosion rate to be less than that of Alloy 1 [41]. It is also suggested that the aluminium oxide formed was stable and it remained on the surface. The SEM image of Alloy 3 shows a similar case of corrosion products remaining on the surface of the alloy due to presence of ternary Al. In addition, due to grain refinement effect of $\mathrm{Zr}$, the corrosion product formation were more evenly distributed on the surface of Alloy 3 . The finer grain size also improved the corrosion resistance of the alloy [46]. It can be concluded from the SEM images that Alloy 2 and 3 showed better corrosion resistance than Alloy 1, while Alloy 3 showed a more uniform corrosion on its surface. These changes in corrosion performances of the alloys can be attributed to their respective alloying additions.

\section{Conclusions}

The effect of ternary $\mathrm{Al}$ and quaternary $\mathrm{Zr}$ addition on the electrochemical corrosion behavior of bell metal has been conducted. The alloying addition of ternary Al decreased the density of bell metal alloy because $\mathrm{Al}$ itself has a low value of density compared to $\mathrm{Cu}$ and $\mathrm{Sn}$. But the hardness value was increased due to the formation of $\mathrm{Al}_{2} \mathrm{Cu}, \mathrm{Cu}_{3} \mathrm{Al}_{2}, \mathrm{Al}_{4} \mathrm{Cu}_{9}$ intermetallic precipitates. Quaternary $\mathrm{Zr}$ addition accelerated the hardness even more due to its grain refining effect. The EIS result shows that higher charge transfer resistance $\left(R_{c t}\right)$ has been obtained in case of both $\mathrm{Al}$ and $\mathrm{Zr}$ added alloys. From Tafel Polarization Curve it is found that the ternary $\mathrm{Al}$ and quaternary $\mathrm{Zr}$ addition reduced the corrosion rate (mpy) of bell metal by creating stable film of aluminium oxide. Following that they also showed very low value of current density $\left(I_{c o r r}\right)$ compared with the base bell metal alloy. The corrosion potential $\left(\mathrm{E}_{\mathrm{corr}}\right)$ and the magnitude of open circuit potential $(\mathrm{OCP})$ were found to be gone to more noble direction for them. The microstructure and SEM study showed that the base alloy suffered a more severe form of corrosion, as there were evidence of localized corrosion taking place. Due to dissolution of corrosion product into the surrounding matrix, there were formation of pits on the alloy surface. In contrast the ternary Al added alloy and quaternary $\mathrm{Zr}$ added alloy showed better resistance to corrosion, characterized by the corrosion products still remaining on the alloy surfaces and a lack of dissolution into the surrounding matrix. Moreover, the $\mathrm{Zr}$ added alloy showed a more uniform form of corrosion due to its more refined grain structure.

\section{Acknowledgement}

The authors are thankful to Directorate of Advisory, Extension and Research Services (DAERS), Bangladesh University of Engineering and Technology, Dhaka, Bangladesh and Pilot Plant and Process Development Centre (PP \& PDC), BCSIR, Dhaka, Bangladesh for providing the laboratory facilities. 


\section{References}

[1] Chang, T., Herting, G., Goidanich, S., Amaya, J.S., Arenas, M.A., Le Bozec, N., Jin, Y., Leygraf, C., Wallinder, I.O., "The role of Sn on the long-term atmospheric corrosion of binary Cu-Sn bronze alloys in architecture", Corrosion Science, vol. 149, pp. 54-67, 2019.

[2] Audy, J., Audy, K., "Analysis of bell materials: Tin bronzes”, China Foundry, vol. 58 (1), pp. 77-81, 2009.

[3] Strafford, K.N., Newell, R., Audy, K., Audy, J., "Analysis of bell material from the Middle Ages to the recent time", Endeavour, vol. 20(1), pp. 22-27, 1996.

[4] Debut, V., Carvalho, M., Figueiredo, E., Antunes, J., Silva, R., "The sound of bronze: Virtual resurrection of a broken medieval bell", Journal of Cultural Heritage, vol. 19, pp. 544-554, 2016.

[5] Hou, J., Sun, J., Zhan, C., Tian, X., Chen, X., "The structural change of Cu-Sn melt", Science in China Series G: Physics, Mechanics and Astronomy, vol. 50(4), pp. 414420, 2007.

[6] Chattopadhayay, P., "History of high tin bronze and brass of eastern India", Indian Journal of History of Science, vol. 52(2), pp. 231-242, 2017.

[7] Jabłońska, M., Maciąg, T., Nowak, M., Rzychoń, T., Czerny, M., Kowalczyk, K., "Thermal and structural analysis of high-tin bronze of chemical composition corresponding to the composition of the singing bowl", Journal of Thermal Analysis and Calorimetry, vol. 137(3), pp. 735-741, 2019.

[8] Weber, K., Kuhn, H.A., "Lead-Free Wrought Copper Alloys for Bushings and Sliding Elements" in Copper Alloys-Early Applications and Current Performance-Enhancing Processes, InTech, 2012, pp. 69-92.

[9] Tyler, D.E., Black, W.T., "Introduction to copper and copper alloys", ASM International, Metals Handbook, Tenth Edition, vol. 2, pp. 216-240, 1990.

[10] Kaiser, M.S., Qadir, M.R., Dutta, S., "Electrochemical corrosion performance of commercially used aluminium engine block and piston in $0.1 \mathrm{M} \mathrm{NaCl",} \mathrm{Journal} \mathrm{of}$ Mechanical Engineering, vol. 45(1), pp. 48-52, 2015.

[11] Ahmad, Z., Principles of corrosion engineering and corrosion control, Elsevier, Sep $18,2006$.

[12] Shaw, B.A., Kelly, R.G., "What is corrosion?", Interface-Electrochemical Society, vol. 15(1), pp. 24-27, 2006.

[13] Choi, W., Shin, H.C., Kim, J.M., Choi, J.Y., Yoon, W.S., "Modeling and Applications of Electrochemical Impedance Spectroscopy (EIS) for Lithium-ion Batteries", Journal of Electrochemical Science and Technology, vol. 11(1), pp. 1-3, 2020.

[14] Kim, Y.H., Kwon, Y.S., Shon, M.Y., Moon, M.J., "Corrosion Protection Performance of PVDF/PMMA-Blended Coatings by Electrochemical Impedance Methods", $J$. Electrochem. Sci. Technol., vol. 9, pp. 1-8, 2018.

[15] Hazani, N.N., Mohd. Y., Ghazali. S.A., Farina, Y., Dzulkifli, N.N., "Electrochemical Studies on Corrosion Inhibition Behaviour of Synthesised 2-acetylpyridine 4-ethyl-3- 
thiosemicarbazone and Its Tin (IV) Complex for Mild Steel in 1 M HCl Solution", Journal of Electrochemical Science and Technology, vol. 10(1), pp. 29-36, 2019.

[16] Nara, H., Yokoshima, T., Osaka, T., "Technology of Electrochemical Impedance Spectroscopy for an Energy-Sustainable Society", Current Opinion in Electrochemistry, vol. 20, pp. 66-77, 2020.

[17] Nadolski, M., "The evaluation of mechanical properties of high-tin bronzes", Archives of Foundry Engineering, vol. 17(1), pp. 127-130, 2017.

[18] Rzadkosz, S., Garbacz-Klempka, A., Kozana, J., Piękoś, M., Czekaj, E., PerekNowak, M., "Research of aluminium influence on tin bronzes", Archives of Foundry Engineering, vol. 15, 2015.

[19] Altuncu, E., Iric, S., Ustel, F., "Wear-resistant intermetallic arc spray coatings", Materials and technology, vol. 46(2), pp. 181-183, 2012.

[20] Deane, K., Sanders, P., "Effect of $\mathrm{Zr}$ Additions on Thermal Stability of Al-Cu Precipitates in As-Cast and Cold Worked Samples", Metals, vol. 8(5), pp. 331, 2018.

[21] Tsivoulas, D., Robson, J.D., "Heterogeneous $\mathrm{Zr}$ solute segregation and $\mathrm{Al}_{3} \mathrm{Zr}$ dispersoid distributions in Al-Cu-Li alloys", Acta Materialia, vol. 93, pp. 73-86, 2015.

[22] Scott, K., "Electrochemical principles and characterization of bioelectrochemical systems" in Microbial Electrochemical and Fuel Cells, Woodhead Publishing, 2016, pp. 29-66.

[23] Kakaei, M.N., Neshati, J., Rezaierod, A.R., "On the Extraction of the Effective Capacitance from Constant Phase Element Parameters", Protection of Metals and Physical Chemistry of Surfaces, vol. 54(3), pp. 548-556, 2018.

[24] Hossain, A., Gafur, M.A., Gulshan, F., Kurny, A.S., "The Effects of 2wt\% Cu Addition on the Corrosion Behavior of Heat Treated Al-6Si-0.5 Mg-2Ni Alloy", International Journal of Materials and Metallurgical Engineering, vol. 8(7), pp. 719723, 2014.

[25] Buchanan, R.A., Stansbury, E.E., "Electrochemical corrosion" in Handbook of environmental degradation of materials, $2^{\text {nd }}$ ed. William Andrew Publishing, 2012, pp. 87-125.

[26] Kaiser, M.S., “Ageing Behaviour of Minor Sc and Zr Doped Cast Cu-10Al Alloys", International Journal of Engineering and Information Systems, vol. 3(11), pp. 7-14, 2019.

[27] Arias, D., Abriata, J.P., “Cu-Zr (copper-zirconium)”, Journal of Phase Equilibria, vol. 11(5), pp. 452-459, 1990.

[28] Kaiser, S., Kaiser, M.S., "Investigation of Mg and Zr Addition on the Mechanical Properties of Commercially Pure Al", International Journal of Mechanical and Materials Engineering, vol. 13(9), pp. 607-611, 2019.

[29] Bell, S., Davis, B., Javaid, A., Essadiqi, E., "Final Report on Effect of Impurities in Aluminum" Report No. 2003-20(CF), 2006.

[30] Ateya, B.G., Ashour, E.A., Sayed, S.M., "Corrosion of $\alpha$-al bronze in saline water", Journal of The Electrochemical Society, vol. 141(1), pp. 71, 1994. 
[31] Charai, A., Hörnström, S.E., Thomas, O., Fryer, P.M., Harper, J,M., “A comparison between aluminum and copper interactions with high-temperature oxide and nitride diffusion barriers", Journal of Vacuum Science \& Technology A: Vacuum, Surfaces, and Films, vol. 7(3), pp. 784-789, 1989.

[32] Vargel, C., Corrosion of aluminium, Elsevier, Dec 30, 2004.

[33] Wang, F., Qiu, D., Liu, Z.L., Taylor, J.A., Easton, M.A., Zhang, M.X., "The grain refinement mechanism of cast aluminium by zirconium", Acta materialia, vol. 61(15), pp. 5636-5645, 2013.

[34] Scott, D.A., Metallography and microstructure in ancient and historic metals, Getty publications, 1992, pp. 25-29.

[35] Stefanescu, D.M., Ruxanda, R., "Solidification Structure of Aluminum Alloys" in ASM Handbook: Metallography and Microstructures, vol. 9, ASM International, 2004, pp. 107-115.

[36] Kaiser, S., Kaiser, M.S., "Influence of Aluminium and Zinc Additives on the Physical and Thermal Behaviour of Cast Copper" Journal of Sustainable Structures and Materials, vol. 3(1), pp. 1-9, 2020.

[37] Mahmoud, A.E., Mahfouz, M.G., Gad-Elrab, H.G., "Influence of zirconium on the grain refinement of Al 6063 alloy", Engineering Research and Applications, vol. 4(7), pp. 188-94, 2014.

[38] Yongdong, H., Xinming, Z., Zhiqiang, C., "Effect of minor Cr, Mn, Zr, Ti and B on grain refinement of as-cast $\mathrm{Al}-\mathrm{Zn}-\mathrm{Mg}-\mathrm{Cu}$ alloys", Rare Metal Materials and Engineering, vol. 39(7), pp. 1135-1140, 2010.

[39] Dvořák, J., Král, P., Kvapilová, M., Svoboda, M., Sklenička, V., "Microstructure Stability and Creep Behaviour of a Cu- 0.2 wt.\% Zr Alloy Processed by Equal-Channel Angular Pressing”, in Materials Science Forum, vol. 667, pp. 821-826, 2011.

[40] Benedeti, A.V., Sumodjo, P.T., Nobe, K., Cabot P.L., Proud, W.G., "Electrochemical studies of copper, copper-aluminium and copper-aluminium-silver alloys: impedance results in 0.5 M NaCl”, Electrochimica Acta, vol. 40(16), pp. 2657-68, 1995.

[41] Liu, B., Liu, J., Liu, Y., Gong, S., Dai, Y., Zhao, G., Xie, G., Peng, L., Li, Z., "Effects of $\mathrm{Al}$ addition on corrosion behavior and mechanical property of high-strength and high-elasticity $\mathrm{Cu}-20 \mathrm{Ni}-20 \mathrm{Mn}-0.3 \quad \mathrm{Nb}-0.3 \quad \mathrm{Cr}-0.3 \quad \mathrm{Zr}$ alloy”, Materials Characterization, vol. 167, pg. 110476, 2020.

[42] Kim, Y.S., Park, J.G., An, B.S., Lee, Y.H., Yang, C.W., Kim, J.G., "Investigation of Zirconium Effect on the Corrosion Resistance of Aluminum Alloy Using Electrochemical Methods and Numerical Simulation in an Acidified Synthetic Sea Salt Solution", Materials, vol. 11(10), pp. 1982, 2018.

[43] Kairy, S.K., Rouxel, B., Dumbre, J., Lamb, J., Langan, T.J., Dorin, T., Birbilis, N., "Simultaneous improvement in corrosion resistance and hardness of a model 2xxx series Al-Cu alloy with the microstructural variation caused by $\mathrm{Sc}$ and $\mathrm{Zr}$ additions", Corrosion Science, vol. 158, pp. 108095, 2019.

[44] Tsao, L.C., Chen, C.W., "Corrosion characterization of $\mathrm{Cu}-\mathrm{Sn}$ intermetallics in 3.5 wt. \% NaCl solution", Corrosion science, vol. 63, pp. 393-398, 2012. 
[45] Ding, P.J., Lanford, W.A., Hymes, S., Murarka, S.P., "Effects of the addition of small amounts of Al to copper: Corrosion, resistivity, adhesion, morphology, and diffusion", Journal of applied physics, vol. 75(7), pp. 3627-3631, 1994.

[46] Song, G., StJohn, D., "The effect of zirconium grain refinement on the corrosion behaviour of magnesium-rare earth alloy MEZ", Journal of Light Metals, vol. 2(1), pp. 1-6, 2002. 